\title{
Voluntary Corporate Governance Disclosure (VCGR) Versi Investor dan Determinan VCGR di Indonesia
}

\author{
Anyta, Siti Mutmainah \\ Program Studi Akuntansi FEB Universitas Diponegoro Semarang \\ Jl. Prof. Soedharto, SH. Tembalang, Semarang, Jawa Tengah \\ E-mail: titihasyim@yahoo.com
}

\begin{abstract}
The purposes of this research are (1) to know the importance level of voluntary corporate governance disclosure (VCGD) in investor version and (2) to know the factual VCGD which is done by public companies in Indonesia and (3) to test determinants of VCGD existence in annual reports of public companies in Indonesia. The determinant of VCGD is a set of corporate governance mechanisms i.e. ownership structure and control mechanisms of the organ of the company, including (1) the concentration of ownership, (2) institutional ownership, (3) the percentage of tradable shares, (4) the proportion of independent commissioners, and (5) the independence of the audit committee.

To know the rate of VCGD's importance, the questionaires was distributed to investors by $e^{-}$ mail. The mean score was used to indicate the importance level of each VCGD's item in investors version. Based on this result then the relative disclosure index was calculated. A total of 74 annual reports of companies which was chosen by purposive sampling method. To test the determinants of level of VCGD, regression analysis was used.

The results show that: (1)The capability and integrity of board of director and public access of companies' information are the two most important items based on investor's opinions; (2) As a whole, public companies in Indonesia have higher level of VCGD then China's which has shown by Yuen, et al. (2009); (3) The percentage of tradable shares (public ownership) is the only independent variable that has a positive and significant, while the other independent variables show no significant effect. This study provides empirical evidence for policy makers and regulators of Indonesia to improve the corporate governance mechanisms and transparency of public companies. These findings also contribute to improving the understanding of disclosure behavior among companies listed in Indonesia Stock Exchange (BEI).
\end{abstract}

Keywords: Corporate Governance, Voluntary Disclosure, Annual Report, Relative Disclosure Index

\section{PENDAHULUAN}

Transparansi dan distribusi informasi yang merata di kalangan pelaku pasar modal pada umumnya, dan investor pada khususnya, akan sangat menentukan keefektifan fungsi pasar modal. Menurut Ho dan Wong (2001), krisis keuangan Asia pada tahun 1997 tidak hanya diakibatkan oleh hilangnya kepercayaan investor, tetapi juga dari kurangnya tata kelola perusahaan yang efektif dan transparansi pada banyak pasar keuangan Asia dan perusahaan individu di akhir tahun 1990-an. Berbagai kasus kegagalan dan skandal perusahaan besar baik di dalam maupun di luar negeri, serta krisis keuangan global tahun 2008 telah mendorong investor untuk lebih memperhatikan pengungkapan informasi perusahaan yang bersifat sukarela (voluntary disclosure).

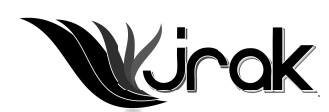

Jurnal Reviu Akuntansi dan Keuangan ISSN: 2088-0685 Vol.2 No. 2, Oktober 2012 Pp 301-312 
VCGR

Versi

Investor...

302
Secara umum diketahui bahwa pengungkapan (disclosure) merupakan salah satu prinsip yang sangat mendasar dalam sistem tata kelola perusahaaan, yakni transparansi. Pengungkapan wajib maupun pengungkapan sukarela adalah cara yang efektif untuk mempublikasikan informasi terkait kondisi perusahaan kepada para stakeholder (pemangku kepentingan). Setiap informasi yang dipublikasikan ke pasar dapat membentuk persepsi pasar yang, setelah itu, dapat memberikan keuntungan ataupun kerugian bagi perusahaan.

Istilah Corporate Governance (CG) pertama kali diperkenalkan oleh Cadbury Committee tahun 1992 dalam laporannya yang dikenal sebagai Cadbury Report. $C G$ merupakan salah satu elemen kunci dalam meningkatkan efisiensi ekonomi dan pertumbuhan serta meningkatkan kepercayaan investor. $C G$ melibatkan satu set hubungan antara manajemen perusahaan, dewan, pemegang saham dan pemangku kepentingan lainnya (OECD Principles of Corporate Governance, 2004).

Komite Nasional Kebijakan Governance (KNKG) (sebelumnya: KNKCG atau Komite Nasional Kebijakan Corporate Governance, 1999) merupakan komite yang dibentuk pemerintah Indonesia yang bertugas merekomendasikan dan mengeluarkan Pedoman Umum Good Corporate Governance Indonesia (terakhir direvisi tahun 2006). Pedoman Umum GCG yang dikeluarkan KNKG (2006) ini bukanlah merupakan peraturan perundangan, sehingga masing-masing perusahaan diharapkan mempraktikkan GCG atas dasar kesadaran sendiri. Akan tetapi prinsipprinsip yang termuat dalam Pedoman Umum GCG ini diharapkan dapat menjadi acuan bagi regulator (BAPEPAM, BAPEPAM-LK, dan BEI) dalam menetapkan peraturan-peraturan sehingga mendukung meluasnya praktek $G C G$ di Indonesia.

Good Corporate Governance (GCG) harus memberikan insentif yang tepat bagi manajemen dan dewan guna mencapai tujuan yang menjadi kepentingan perusahaan dan para pemegang saham, serta harus memfasilitasi pengawasan yang efektif. Adanya sistem tata kelola perusahaan yang efektif, dalam sebuah perusahaan individu dan suatu perekonomian secara keseluruhan, membantu menyediakan level kepercayaan yang diperlukan untuk berfungsinya ekonomi pasar. Akibatnya, biaya modal menjadi lebih rendah dan perusahaan didorong untuk menggunakan sumber daya secara lebih efisien, sehingga mendasari pertumbuhan (OECD Principles of Corporate Governance, 2004).

Menyadari pentingnya mekanisme $C G$ dan kecukupan pengungkapan $C G$, maka penting untuk melakukan studi yang memfokuskan pada tingkat pengungkapan praktek $C G$ antara perusahaan di Indonesia. Hal ini didukung dengan adanya Lampiran Keputusan Ketua BAPEPAM-LK Nomor KEP-134/BL/2006, Peraturan Nomor X.K.6 tentang Kewajiban Penyampaian Laporan Tahunan Bagi Emiten atau Perusahaan Publik, yang di dalamnya terdapat ketentuan umum mengenai bentuk dan isi laporan tahunan, yang salah satunya mewajibkan perusahaan publik untuk memuat uraian singkat mengenai pelaksanaan praktik tata kelola perusahaan.

Penelitian yang menguji pengaruh mekanisme $C G$ terhadap tingkat pengungkapan praktek $C G$ telah dilakukan antara lain oleh Yuen et al. (2009) di China, serta Mohammad dan Sulong (2010) di Malaysia. Penelitian Yuen et al. (2009) memfokuskan tingkat pengungkapan praktek $C G$ pada item pengungkapan yang bersifat sukarela (Voluntary Corporate Governance Disclosure, VCGD). Di Indonesia, penelitian mengenai tingkat pengungkapan praktek $C G$ telah dilakukan oleh Kusumawati (2007), Safitri (2008), dan Rini (2010). Akan tetapi ketiga penelitian tersebut tidak memisahkan antara item pengungkapan wajib dan item pengungkapan sukarela. Penelitian mengenai level pengungkapan sukarela secara umum di Indonesia oleh Vasthi (2009), Simanjuntak (2009), Subroto (2009), dan Wijayanti (2009) juga belum menunjukkan hasil yang konsisten. Berdasarkan hipotesis transaksi pasar modal dalam Healy dan Palepu (2001), pengungkapan sukarela merupakan salah satu cara untuk meminimalkan asimetri informasi dalam perusahaan. Selain itu pengungkapan yang memang telah diwajibkan oleh regu- 
lator dirasa belum memenuhi kebutuhan informasi yang ingin investor dapatkan dari laporan tahunan perusahaan (Hrasky dan Collet, 2005). Dengan mempertimbangkan hal-hal tersebut maka penelitian ini hanya akan berfokus pada analisis tingkat pengungkapan $C G$ yang bersifat sukarela saja (VCGD).

Penelitian ini mengacu pada penelitian Yuen et al. (2009). Daftar item VCGD yang digunakan dalam penelitian ini bersumber dari Pedoman Umum GCG tahun 2006. Seluruh item pengungkapan $C G$ tersebut lalu dibandingkan dengan peraturan/perundang-undangan terkait yang dikeluarkan oleh regulator (KEP-29/ PM/2004; KEP- 45/PM/2004; KEP-82/PM/1996; KEP-86/PM/1996; dan KEP-134/ $\mathrm{BL} / 2006$ ), untuk kemudian ditentukan apakah item-item tersebut tergolong item pengungkapan wajib atau sukarela.

Setelah itu disusunlah daftar item VCGD dalam bentuk kuesioner yang kemudian disebarkan pada 100 responden untuk diberi skor tentang tingkat kepentingan suatu item VCGD. Dalam penelitiannya, Yuen et al. (2009) mengirimkan 100 kuesioner kepada 100 financial analyst dari Bank of China. Berbeda dengan Yuen et al. (2009), penelitian ini lebih memfokuskan penilaian aspek VCGD dari perspektif investor, sehingga responden yang digunakan dalam penelitian ini lebih mengarah pada profesi-profesi yang terlibat langsung dalam pengambilan keputusan investasi, yaitu individual investor (trader), equity analyst pada perusahaan sekuritas atau reksadana, dan pialang (broker). Selanjutnya dilakukan pengujian pengaruh seperangkat mekanisme $C G$ yang meliputi struktur kepemilikan dan mekanisme kontrol atas organ perusahaan terhadap tingkat VCGD di Indonesia. Seperangkat mekanisme $C G$ yang merupakan variabel independen dalam penelitian ini meliputi konsentrasi kepemilikan, persentase saham yang diperdagangkan (tradable shares), kepemilikan institusional, proporsi komisaris independen, dan independensi komite audit.

Penelitian ini bertujuan untuk mengetahui (1) bagaimana tingkat kepentingan VCGD dalam perspektif investor, (2) bagaimana level VCGD yang dilakukan perusahaan publik di Indonesia, dan (3) apakah mekanisme CG yaitu struktur kepemilikan dan mekanisme kontrol mencakup konsentrasi kepemilikan, kepemilikan institusional, persentase saham yang diperdagangkan, proporsi komisaris independen dan ind0ependensi komite audit berpengaruh terhadap tingkat VCGD.

\section{PERUMUSAN HIPOTESIS}

\section{Konsentrasi Kepemilikan dan Pengaruhnya terhadap Tingkat VCGD}

Yuen, et al. (2009) berpendapat bahwa pemegang saham pengendali mungkin akan kurang tergantung pada transparansi dan pengungkapan informasi, dan mereka mendapatkan informasi secara langsung dari saluran informal. Dengan demikian diasumsikan bahwa perusahaan dengan struktur kepemilikan terpusat akan menjadi enggan untuk mengungkapkan informasi tambahan (informasi yang bersifat sukarela). Oleh karena itu hipotesis pertama yang akan diuji dalam penelitian ini adalah:

H1: Konsentrasi kepemilikan berpengaruh negatif terhadap tingkat pengungkapan tata kelola perusahaan yang bersifat sukarela

\section{Kepemilikan Institusional serta Pengaruhnya terhadap Tingkat VCGD}

Kepemilikan institusional merupakan bentuk kepemilikan saham suatu perusahaan oleh satu atau lebih institusi (lembaga). Institusi atau lembaga di sini dapat berupa bank, perusahaan investasi, ataupun perusahaan lainnya. Studi terbaru menunjukkan bahwa tingkat pengungkapan sukarela perusahaan akan lebih tinggi jika kelompok dominan pemegang saham terdiri dari pihak di luar perusahaan. Sebaliknya, jika kelompok dominan pemegang saham terdiri dari orang dalam, tingkat pengungkapan akan menjadi lebih rendah (Maingot and 
VCGR

Versi

Investor...

304

Zeghal, 2008). Kepemilikan institusional merupakan salah satu bentuk dari kepemilikan outsider (kepemilikan oleh pihak di luar perusahaan). Semakin tinggi kepemilikan institusional maka akan semakin efektif monitoring yang dilakukan pemegang saham terhadap kinerja manajemen. Oleh karena itu, dari sudut pandang stakeholder theory, manajemen akan merespon hal tersebut dengan cara meningkatkan level pengungkapan sukarela. Berdasarkan hal tersebut, hipotesis yang diajukan dalam penelitian ini adalah:

H2: Kepemilikan institusional berpengaruh positif terhadap tingkat pengungkapan tata kelola perusahaan yang bersifat sukarela

\section{Persentase Saham yang Diperdagangkan dan Pengaruhnya terhadap Tingkat VCGD}

Perusahaan publik diwajibkan untuk senantiasa memenuhi persyaratan listing dan meningkatkan level transparansi. Michael, et al. (2002) dalam Yuen, et al. (2009) menemukan bahwa perusahaan dengan jumlah saham yang diperdagangkan yang lebih banyak mengungkapkan strategi dan informasi keuangan secara lebih signifikan. Demikian halnya hasil penelitian Yuen, et al. (2009) yang menunjukkan bahwa peningkatan jumlah saham yang diperdagangkan mempunyai pengaruh yang positif dan signifikan terhadap luas $V C G D$. Dari perspektif perusahaan, perusahaan diharuskan menyediakan lebih banyak informasi kepada investor potensial guna meningkatkan daya tarik saham perusahaan di pasar modal (Meek et al., 1995, dalam Yuen, et al. 2009). Karena itu, diajukan hipotesis:

H3: Persentase saham yang diperdagangkan (tradable shares) berpengaruh positif terhadap tingkat pengungkapan tata kelola perusahaan yang bersifat sukarela

\section{Proporsi Komisaris Independen dan Pengaruhnya terhadap Tingkat VCGD}

Komisaris Independen merupakan bagian dari Dewan Komisaris yang tidak berasal dari pihak terafiliasi. Cheng dan Courtenay (2006) dalam Yuen, et al. (2009) meneliti hubungan antara independensi Dewan Komisaris dan luas pengungkapan sukarela. Mereka menemukan bahwa perusahaan dengan proporsi Komisaris Independen yang lebih tinggi memiliki level pengungkapan sukarela yang lebih tinggi pula. Keberadaan mekanisme pengendalian eksternal serta peraturan lingkungan, meningkatkan kekuatan hubungan antara proporsi Komisaris Independen dan level pengungkapan sukarela. Ketika komposisi Komisaris Independen dalam suatu perusahaan lebih tinggi maka perusahaan tersebut diharapkan melakukan lebih banyak pengungkapan sukarela, sehingga dapat mengurangi kemungkinan terjadinya withholding information (penahanan informasi) oleh manajemen.

H4: Proporsi komisaris independen berpengaruh positif terhadap tingkat pengungkapan tata kelola perusahaan yang bersifat sukarela

\section{Independensi Komite Audit dan Pengaruhnya terhadap Luas VCGD}

Komite Audit merupakan salah satu mekanisme kontrol atas organ perusahaan yang sangat penting dalam meningkatkan transparansi perusahaan dan mendorong manajemen agar mengungkapkan lebih banyak informasi. Untuk dapat memenuhi fungsi pengawasan Komite Audit secara efektif, Komite Audit harus terdiri dari sumber daya yang memadai, independen, kompeten, mendalami bidang keuangan (financially literate), dan dikompensasi dengan tepat (Yuen, et al., 2009). Oleh karena itu hipotesis dalam penelitian ini adalah:

H5: Independensi Komite Audit berpengaruh positif terhadap tingkat pengungkapan tata kelola perusahaan yang bersifat sukarela 
Langkah awal penelitian ini adalah penyusunan daftar item VCGD. Pedoman Umum GCG Tahun 2006 (KNKG) merekomendasikan 105 item pengungkapan $C G$ yang dikelompokkan dalam 16 kategori. Seluruh item pengungkapan $C G$ tersebut dibandingkan dengan peraturan/perundang-undangan terkait (KEP-29/PM/ 2004; KEP- 45/PM/2004; KEP-82/PM/1996; KEP-86/PM/1996; dan KEP-134/BL/ 2006), untuk kemudian ditentukan apakah item-item tersebut tergolong item pengungkapan wajib atau sukarela.

Dari hasil pemeriksaan tersebut di atas, akhirnya diperoleh 11 kategori yang terdiri dari 34 item VCGD. Setelah daftar item VCGD terbentuk, disusunlah sebuah kuesioner yang berisi 34 item VCGD untuk kemudian dikirimkan kepada 100 res- $^{-}$ ponden yang terdiri dari profesi-profesi yang terlibat langsung dalam pengambilan keputusan investasi, yaitu individual investor (trader), equity analyst pada perusahaan sekuritas atau reksadana, dan pialang (broker). Seratus (100) responden tersebut diminta untuk menentukan derajat kepentingan dari masing-masing item $V C G D$ tersebut dengan skala poin 1 s/d 7 , item $V C G D$ dengan minimum skala poin 4 dipertahankan dalam daftar dan lainnya dieliminasi, sehingga nantinya akan terbentuk daftar frekuensi tingkat kepentingan item VCGD yang dianggap penting oleh responden. Daftar inilah yang nantinya akan digunakan untuk menentukan skor masing-masing item VCGD yang diungkapkan oleh perusahaan sampel.

Pengukuran tingkat VCGD suatu perusahaan (IPR), menggunakan metode analisis isi (content analysis). Analisis isi (content analysis) secara sederhana diartikan sebagai metode untuk mengumpulkan dan menganalisis muatan dari sebuah "teks". Dalam penelitian ini, "teks" diartikan sebagai item-item VCGD yang diungkapkan oleh perusahaan. Prosesnya meliputi pemeriksaan dan pemberian skor terhadap item-item pengungkapan VCGD apa saja yang diungkapkan dalam laporan tahunan masing-masing perusahaan. Skor yang diberikan mengacu pada daftar frekuensi pengungkapan item-item VCGD yang dianggap penting oleh responden. Berbeda dengan penelitian sebelumnya, metode yang digunakan dalam pengukuran tingkat $V C G D$ ini adalah indeks rata-rata tertimbang atau dikenal dengan sistem pembobotan. Pemilihan metode ini diharapkan dapat memberikan hasil yang lebih akurat, mengingat ketidakkonsistenan hasil penelitian terdahulu yang hampir semuanya menggunakan nilai dikotomis.

Dengan demikian akan diperoleh tingkat VCGD masing-masing perusahaan, yang diberi simbol IPR (Indeks Pengungkapan Relatif), yang kemudian menjadi variabel dependen untuk mencapai tujuan penelitian ke-3. Seperti yang dilakukan oleh Yuen et al. (2009), IPR masing-masing perusahaan dihitung dengan cara membandingkan jumlah rata-rata skor aktual perusahaan dengan jumlah ratarata skor maksimal yang mungkin diperoleh perusahaan.

\section{Konsentrasi Kepemilikan}

Konsentrasi kepemilikan diukur dengan menggunakan persentase kepemilikan pemegang saham mayoritas dalam perusahaan, di luar saham yang dimiliki oleh publik.

\section{Kepemilikan Institusional}

Informasi mengenai proporsi kepemilikan saham oleh institusi (lembaga) dapat diperoleh dalam laporan tahunan perusahaan publik. Kepemilikan institusional dapat pula dihitung dengan membandingkan proporsi saham yang dimiliki oleh institusi (lembaga) dengan jumlah saham yang diterbitkan perusahaan. 
VCGR

Versi

Investor...

306

Persentase Jumlah Saham yang Diperdagangkan (Tradable Shares)

Variabel ini dinotasikan dengan "TS". Persentase jumlah saham yang diperdagangkan mencerminkan jumlah kepemilikan masyarakat atau publik yang dapat dihitung dengan membandingkan proporsi saham yang diperdagangkan dengan jumlah saham yang diterbitkan.

\section{Proporsi Komisaris Independen}

Proporsi Komisaris Independen diukur dengan membandingkan proporsi jumlah anggota Komisaris Independen dengan jumlah seluruh anggota Dewan Komisaris yang ada di perusahaan.

\section{Independensi Komite Audit}

Independensi Komite Audit diukur dengan membandingkan proporsi jumlah anggota Komite Audit independen dan jumlah seluruh anggota Komite Audit.

\section{Populasi dan Sampel Penelitian}

Berdasarkan FactBook 2010 (http://www.idx.co.id) jumlah perusahaan yang terdaftar di BEI (listing) selama periode tahun 2009 berjumlah 414 perusahaan. Populasi dalam penelitian ini adalah seluruh perusahaan yang sahamnya terdaftar di Bursa Efek Indonesia (BEI), tidak termasuk perusahaan perusahaan yang delisted, yaitu 406 perusahaan. Sektor finance dikeluarkan dari sampel akhir karena perusahaan dalam sektor tersebut memiliki struktur modal yang berbeda dengan sektor lainnya (Yuen et al. 2009). Pertimbangan lainnya adalah telah diterbitkannya Pedoman GCG Perbankan Indonesia pada awal tahun 2004 dan Pedoman GCG Perasuransian Indonesia pada awal tahun 2006 oleh KNKG.

Berdasarkan populasi tersebut akan ditentukan sampel sebagai objek penelitian. Teknik pemilihan sampel yang digunakan adalah purposive sampling, dengan kriteria sebagai berikut:

1. perusahaan tersebut mempublikasikan annual report tahun 2009 yang dapat diakses melalui website perusahaan dan website BEI (http://www.idx.co.id). Ini menunjukkan bahwa informasi yang terdapat dalam annual report perusahaan dapat diakses oleh publik dengan mudah (accessible);

2. sektor finance dikeluarkan dari sampel akhir karena perusahaan dalam sektor tersebut memiliki struktur modal yang berbeda dengan sektor lainnya (Yuen, et al., 2009) dan sektor tersebut mempunyai Pedoman GCG khusus selain Pedoman Umum GCG Indonesia Tahun 2006.

3. kelengkapan data perusahaan.

4. distribusi unstandardized data normal.

\section{Jenis dan Sumber Data}

Penelitian ini menggunakan data primer dan data sekunder. Data primer berupa skor masing-masing item VCGD yang diperoleh melalui kuesioner yang disebar dengan e-mail, sedangkan data sekunder berupa laporan tahunan periode 2009 perusahaan publik (emiten) yang menjadi sampel dalam penelitian ini. Sumber data sekunder yang digunakan merupakan publikasi masing-masing emiten pada website perusahaan dan website BEI (www.idx.co.id).

Proses pengumpulan kuesioner dalam penelitian ini membutuhkan waktu kurang lebih 3 (tiga) bulan. Kuesioner penelitian dikirimkan kepada 100 orang responden, yang merupakan profesi-profesi yang terlibat langsung dalam pengambilan keputusan investasi, yaitu individual investor (trader), equity analyst pada perusahaan sekuritas atau reksadana, dan pialang (broker). Alamat e-mail masingmasing calon responden, didapatkan melalui "Analytical Review" yang dipublikasi- 
kan oleh beberapa perusahaan sekuritas di Indonesia dan dapat diakses melalui internet, antara lain: PT Trimegah Securities, Tbk; PT Reliance Securities, Tbk; PT Kresna Graha Sekurindo, Tbk; PT Majapahit Securities, Tbk; PT Danareksa Sekuritas, Tbk; PT Indo Premier Securities, Tbk; PT Valbury Asia Securities, Tbk; PT Universal Broker Indonesia, Tbk; dan partisipan milis "saham@yahoogroups.com”.

Kurun waktu pengumpulan respon data kuesioner dalam penelitian ini terbilang cukup lama. Pengiriman e-mail kepada 100 orang responden dilakukan secara periodik, yaitu pada tanggal 12 Desember 2010; 17 Desember 2010; 24 Desember 2010; 3 Januari 2011; 14 Januari 2011; 21 Januari 2011; 25 Januari 2011; 2 Februari 2011; dan 1 Maret 2011. Hal ini dimaksudkan agar penelitian ini memperoleh jumlah responden yang memadai. Sampai dengan tanggal 7 Maret 2011, akhirnya berhasil diperoleh 37 e-mail dari responden.

\section{Metode Analisis Data}

Statistik deskriptif digunakan untuk menggambarkan variabel-variabel dalam penelitian ini. Sebelum dilakukan pengujian hipotesis dengan menggunakan analisis regresi berganda, dalam penelitian ini digunakan uji asumsi klasik.

Model persamaan regresi berganda digunakan untuk menguji pengaruh mekanisme corporate governance terhadap Voluntary Corporate Governance Disclosure (VCGD) dalam penelitian ini dapat dijabarkan sebagai berikut:

\section{$\mathrm{IPR}=\beta 0-\beta 1$ Top10 $+\beta 2 \mathrm{PI}+\beta 3 \mathrm{TS}+\beta 4$ INDs $+\beta 5$ INDAC $+\varepsilon$}

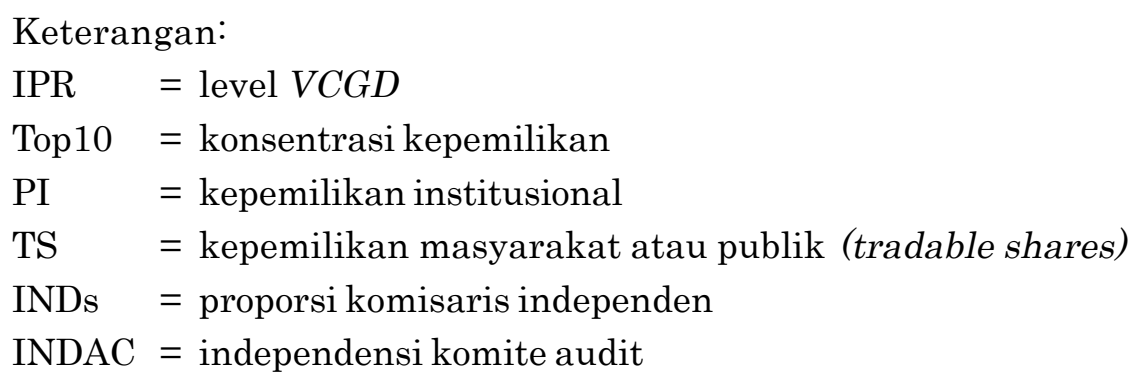

Uji Statistik F dilakukan untuk menguji kemampuan seluruh variabel independen secara bersama-sama dalam menjelaskan perilaku variabel dependen (kelayakan model). Untuk mengetahui kemampuan masing-masing variabel independen dalam menjelaskan perilaku variabel dependen dilakukan uji statistik t. Pengujian dilakukan dengan menggunakan alpha 5\%. Untuk mengetahui seberapa jauh kemampuan model dalam menjelaskan variasi variabel dependen digunakan koefisien determinasi (R2).

\section{HASIL DAN PEMBAHASAN}

\section{Statistik Deskriptif}

Variabel tradable shares yang diukur dengan menggunakan kepemilikan oleh masyarakat (publik) menunjukkan rata-rata sebesar 31,21\%. Nilai minimum sebesar 6\% dimiliki oleh PT Citra Kebun Raya Agri Tbk dan nilai maksimum sebesar 85\% dimiliki oleh PT Fortune Indonesia Tbk. Rata-rata konsentrasi kepemilikan sebesar 47,57\%, dengan nilai terkecil dimiliki oleh PT Fortune Indonesia Tbk, yaitu sebesar 9\%. Sementara perusahaan dengan konsentrasi kepemilikan terbesar adalah PT Indonesia Prima Property Tbk, yaitu sebesar 90\%. Kepemilikan institusional terkecil sebesar 10\%, yaitu PT Sampoerna Agro Tbk dan kepemilikan institusional terbesar, PT Citra Kebun Raya Agri Tbk, sebesar 93\%. Variabel proporsi komisaris independen diukur dengan membandingkan jumlah komisaris independen dengan jumlah seluruh anggota komisaris. Proporsi terkecil dimiliki oleh 
VCGR

Versi

Investor...

308
PT Panorama Transportasi Tbk, yaitu sebesar 20\%. Sementara PT Mobile-8 Telekom Tbk dan PT Steady Safe Tbk memiliki proporsi komisaris independen maksimal, yaitu 100\%. Empat (4) perusahaan yang menjadi sampel dalam penelitian ini, yaitu Radiant Utama Interinsco Tbk, Nusantara Inti Corpora Tbk, Berlian Laju T anker Tbk, dan PT AKR Corporindo Tbk memiliki proporsi independensi komite audit yang paling kecil, yaitu 33\%. Sementara 59 (lima puluh sembilan) perusahaan lainnya, kecuali PT BISI International Tbk, PT Gozco Plantation Tbk, PT Sampoerna Agro Tbk, PT Bumi Resources Tbk, PT Darma Henwa Tbk, PT Elnusa Tbk, PT Adhi Karya (Persero) Tbk, PT Ace Hardware Indonesia Tbk, PT Abdi Bangsa Tbk, PT First Media Tbk, dan PT Bakrie \& Brothers Tbk, memiliki proporsi independensi komite audit maksimal, yaitu 100\%.

\section{Tingkat Kepentingan VCGD versi Investor}

Berdasarkan 37 jawaban kuesioner yang kembali dari 100 kuesioner yang dikirim melalui email pada investor, diketahui bahwa investor merangking kemampuan dan integritas anggota Direksi pada urutan tingkat terpenting pertama (bobot 6,68); dilanjutkan pada urutan berikutnya: uraian mengenai tersedianya akses informasi dan data perusahaan kepada publik, misalnya melalui website, media massa, mailing list, buletin, dan sebagainya pada urutan kedua $(6,41)$. Sedangkan informasi yang dianggap kurang penting adalah uraian mengenai aktivitas SPI selama setahun, dan informasi mengenai fee audit eksternal (bobot 4,43).

\section{Level VCGD Perusahaan Publik}

Untuk mencapai tujuan penelitian kedua dan ketiga, item VCGD (34 item) yang digunakan dalam penelitian ini adalah item yang memiliki skor di atas 4 . Skor IPR maksimum yang mungkin diperoleh perusahaan sebesar 5,59. Dengan demikian, dapat dikatakan kebutuhan akan informasi terkait pengungkapan tata kelola perusahaan yang bersifat sukarela (VCGD) di Indonesia terbilang tinggi.

Dari 406 perusahaan, melalui prosedur penentuan sampel sebagaimana dipaparkan sebelumnya, diperoleh sampel sebanyak 75 perusahaan. Dari tabel diketahui, nilai rata-rata Indeks Pengungkapan Relatif (IPR) VCGD sebesar 0,3967. Hal ini menunjukkan bahwa perusahaan publik di Indonesia telah memiliki tingkat $V C G D$ yang cukup baik apabila dibandingkan dengan tingkat VCGD di China dalam penelitian Yuen, et al. (2009) yang hanya sebesar 0,214. Nilai minimum sebesar 0,11 dimiliki oleh PT Intraco Penta Tbk dan nilai maksimum sebesar 0,88 dimiliki oleh PT Bumi Resources Tbk.

\section{Analisis Regresi Berganda}

Analisis regresi berganda digunakan untuk mengetahui pengaruh variabel independen, yaitu konsentrasi kepemilikan, tradable shares, kepemilikan institusional, proporsi komisaris independen, dan independensi komite audit terhadap tingkat $V C G D$ perusahaan publik di Indonesia. Dari hasil uji statistik diketahui bahwa nilai adjusted $R$ Square sebesar 0,902. Hal ini berarti bahwa 90,2\% variasi tingkat VCGD dapat dijelaskan secara signifikan oleh tradable shares, konsentrasi kepemilikan, kepemilikan institusional, proporsi komisaris independen, dan independensi komite audit, sedangkan 9,8\% variasi tingkat VCGD dijelaskan oleh variabel lainnnya di luar model. Standard Error of Estimate (SEE) sebesar 0,06371 menunjukkan bahwa model regresi dapat memprediksi variabel dependen dengan baik. Hal ini sesuai dengan Ghozali (2006) yang menyatakan bahwa makin kecil nilai $S E E$ akan membuat model regresi semakin tepat dalam memprediksi variabel dependen. 


\begin{tabular}{cccccc}
\hline Model & $\mathbf{R}$ & R Square & $\begin{array}{c}\text { Adjusted R } \\
\text { Square }\end{array}$ & $\begin{array}{c}\text { Std. Error of the } \\
\text { Estimate }\end{array}$ & Durbin-Watson \\
\hline 1 & $.953^{\mathrm{a}}$ & .909 & .902 & .06371 & 2.005 \\
\hline
\end{tabular}

a. Predictors: (Constant), INDAC, INDs, TS, TOP10, PI

b. Dependent Variable: IPR

Dari hasil pengujian dengan nilai $\mathrm{F}$, terlihat bahwa nilai $\mathrm{F}=137,678$ dengan probabilitas signifikansi sebesar 0,000. Karena probabilitas signifikansi lebih kecil dari 0,05, maka dapat disimpulkan bahwa variabel tradable shares, konsentrasi kepemilikan, kepemilikan institusional, proporsi komisaris independen, dan independensi komite audit secara bersama-sama berpengaruh terhadap tingkat VCGD, atau dengan kata lain model regresi adalah fit.

\begin{tabular}{llcrccc}
\hline & Model & Sum of Squares & df & Mean Square & F & Sig. \\
\hline 1 & Regression & 2.794 & 5 & .559 & 137.678 & $.000^{\text {a }}$ \\
& Residual & .280 & 69 & .004 & & \\
& Total & 3.074 & 74 & & & \\
\hline
\end{tabular}

a. Predictors: (Constant), INDAC, INDs, TS, TOP10, PI

b. Dependent Variable: IPR

Dari hasil pengujian variabel konsentrasi kepemilikan terhadap tingkat $V C G D$, dapat diketahui bahwa variabel konsentrasi kepemilikan berpengaruh positif tetapi tidak signifikan terha dap tingkat $V C G D$, yang ditunjukkan oleh nilai koefisien $\mathrm{B}=0,028$ dengan nilai t (hitung) $=0,570$ dan signifikansi sig $=0,571$. Secara statistik berarti tidak terdapat pengaruh positif yang signifikan dari konsentrasi kepemilikan terhadap tingkat VCGD, oleh karena itu dapat disimpulkan bahwa hipotesis pertama ditolak. Hasil penelitian ini konsisten dengan penelitian Yuen, et al. (2009). Menurut Ghazali (2006), hasil yang tidak signifikan ini kemungkinan disebabkan karena tidak adanya klasifikasi konsentrasi kepemilikan. Arah yang berlawanan antara kepemilikan manajerial (negatif) dengan kepemilikan asing, institusional dan pemerintah (positif), menunjukkan bahwa konsentrasi kepemilikan perlu diklasifikasi.

\begin{tabular}{|c|c|c|c|c|c|c|c|}
\hline \multirow[t]{2}{*}{ Model } & \multicolumn{2}{|c|}{$\begin{array}{l}\text { Unstandardized } \\
\text { Coefficients }\end{array}$} & \multirow{2}{*}{$\begin{array}{c}\begin{array}{c}\text { Standardized } \\
\text { Coefficients }\end{array} \\
\text { Beta } \\
\end{array}$} & \multirow[t]{2}{*}{$\mathbf{t}$} & \multirow[t]{2}{*}{ Sig. } & \multicolumn{2}{|c|}{$\begin{array}{l}\text { Collinearity } \\
\text { Statistics }\end{array}$} \\
\hline & B & Std. Error & & & & Tolerance & VIF \\
\hline 1 (Constant) & .035 & .065 & & .530 & .598 & & \\
\hline TS & 1.015 & .070 & .928 & 14.562 & .000 & .325 & 3.077 \\
\hline TOP10 & .028 & .049 & .028 & .570 & .571 & .561 & 1.784 \\
\hline $\mathrm{PI}$ & -.050 & .054 & -.055 & -.935 & .353 & .375 & 2.664 \\
\hline INDs & .015 & .055 & .010 & .281 & .779 & .957 & 1.045 \\
\hline INDAC & .062 & .039 & .061 & 1.614 & .111 & .928 & 1.077 \\
\hline
\end{tabular}

Tabel 1

Model Summary ${ }^{\mathrm{b}}$

Tabel 2

ANOVA $^{\mathrm{b}}$

Tabel 3

Coefficients $^{\mathrm{a}}$

a. Dependent Variable: IPR

Dari hasil pengujian variabel kepemilikan institusional terhadap tingkat VCGD, dapat diketahui bahwa variabel kepemilikan institusional berpengaruh negatif tetapi tidak signifikan terhadap tingkat $V C G D$, yang ditunjukkan oleh nilai koefisien $\mathrm{B}=-0,050$ dengan nilai t (hitung) $=-0,935$ dan signifikansi sig $=0,353$. Secara 
VCGR

Versi

Investor...

310 statistik berarti tidak terdapat pengaruh negatif yang signifikan dari kepemilikan institusional terhadap tingkat VCGD, oleh karena itu dapat disimpulkan bahwa hipotesis kedua ditolak. Pengaruh negatif kepemilikan institusional terhadap tingkat VCGD dalam penelitian ini kemungkinan dikarenakan penelitian ini tidak memisahkan kepemilikan institusional oleh perusahaan yang masih memiliki hubungan afiliasi atau tidak. Dengan kata lain kepemilikan institusional dalam penelitian ini diukur dengan menggunakan persentase kepemilikan saham selain yang dimiliki oleh orang pribadi dan publik, sehingga terdapat pengaruh yang berlawanan (negatif) apabila komposisi kepemilikan institusional terdiri dari kepemilikan oleh perusahaan yang terafiliasi atau insider ownership. Hasil penelitian yang tidak signifikan ini sama dengan hasil penelitian yang dilakukan oleh $V$ asthi (2009). Hal ini menunjukkan masih rendahnya tingkat kesadaran perusahaan untuk melakukan pengungkapan terkait pelaksanaan tata kelola perusahaan yang bersifat sukarela, meskipun persentase kepemilikan saham oleh institusi atau lembaga dalam perusahaan publik di Indonesia tergolong cukup tinggi.

Dari hasil pengujian variabel persentase saham yang diperdagangkan terhadap tingkat $V C G D$, dapat diketahui bahwa variabel persentase saham yang diperdagangkan berpengaruh positif dan signifikan terhadap tingkat VCGD, yang ditunjukkan oleh nilai koefisien $\mathrm{B}=1,015$ dengan nilai t (hitung) $=14,562$ dan signifikansi sig $=0,000$. Secara statistik berarti terdapat pengaruh positif yang signifikan dari persentase saham yang diperdagangkan terhadap tingkat $V C G D$, oleh karena itu dapat disimpulkan bahwa hipotesis ketiga diterima. Hasil penelitian ini berbeda dengan penelitian Rini (2010), Vasthi (2009), Simanjuntak (2009), dan Subroto (2009) yang menunjukkan bahwa tidak terdapat pengaruh yang signifikan antara persentase saham yang diperdagangkan (TS) dengan tingkat pengungkapan informasi tata kelola perusahaan. Akan tetapi, hasil penelitian ini konsisten dengan penelitian Yuen, et al. (2009) dan Wijayanti (2009). Hasil penelitian Yuen, et al. (2009) menunjukkan bahwa peningkatan jumlah saham yang diperdagangkan mempunyai pengaruh yang positif dan signifikan terhadap luas VCGD. Semakin banyak informasi yang diungkapkan oleh perusahaan diharapkan dapat semakin meningkatkan daya tarik saham perusahaan bagi calon investor potensial.

Dari hasil pengujian variabel proporsi komisaris independen terhadap tingkat $V C G D$, dapat diketahui bahwa variabel proporsi komisaris independen berpengaruh positif tetapi tidak signifikan terhadap tingkat $V C G D$, yang ditunjukkan oleh nilai koefisien $\mathrm{B}=0,015$ dengan nilai $\mathrm{t}$ (hitung) $=0,281$ dan signifikansi sig $=0,779$. Secara statistik berarti tidak terdapat pengaruh positif yang signifikan dari proporsi komisaris independen terhadap tingkat $V C G D$, oleh karena itu dapat disimpulkan bahwa hipotesis keempat ditolak. Hasil penelitian ini konsisten dengan penelitian Vasthi (2009) dan Wijayanti (2009). Ini menunjukkan bahwa komposisi komisaris independen yang tinggi dalam perusahaan tidak otomatis menghasilkan tingkat $V C G D$ yang tinggi pula. Hal ini mungkin dikarenakan keputusan mengenai luas pengungkapan maupun item-item pengungkapan apa saja yang akan diungkapkan perusahaan lebih didasarkan pada pertimbangan strategis manajemen.

Dari hasil pengujian variabel independensi komite audit terhadap tingkat $V C G D$, dapat diketahui bahwa variabel independensi komite audit berpengaruh positif tetapi tidak signifikan terhadap tingkat $V C G D$, yang ditunjukkan oleh nilai koefisien $\mathrm{B}=0,062$ dengan nilai t (hitung) $=1,614$ dan signifikansi sig $=0,111$. Secara statistik berarti tidak terdapat pengaruh positif yang signifikan dari independensi komite audit terhadap tingkat VCGD, oleh karena itu dapat disimpulkan bahwa hipotesis kelima ditolak. Hasil penelitian ini konsisten dengan penelitian Mohamad dan Sulong (2010) di Malaysia. Hal ini berarti tingginya komposisi anggota komite audit independen juga tidak menjamin bahwa perusahaan akan melakukan pengungkapan tata kelola perusahaan yang lebih luas. 
Seluruh item VCGD (34 item) yang digunakan dalam penelitian ini memiliki skor di atas 4, dan skor IPR maksimum yang mungkin diperoleh perusahaan sebesar 5,59. Dengan demikian, dapat dikatakan bahwa kebutuhan akan informasi terkait pengungkapan tata kelola perusahaan yang bersifat sukarela (VCGD) di Indonesia terbilang tinggi. Selain itu, hasil analisis deskriptif menunjukkan bahwa nilai rata-rata IPR dalam penelitian ini adalah sebesar 0,3967. Ini menandakan bahwa perusahaan publik di Indonesia telah memiliki tingkat VCGD yang cukup baik apabila dibandingkan dengan tingkat VCGD di China dalam penelitian Yuen, et al. (2009) yang hanya sebesar 0,214 .

Variabel konsentrasi kepemilikan, kepemilikan institusional, proporsi komisaris dan independensi komite audit independen tidak memiliki pengaruh yang signifikan terhadap tingkat VCGD. Tradable shares yang mencerminkan proporsi kepemilikan publik berpengaruh positif dan signifikan terhadap tingkat VCGD.

\section{KETERBATASAN DAN SARAN}

Dalam penelitian ini terdapat beberapa keterbatasan yang kemungkinan dapat mempengaruhi hasil penelitian, antara lain (1) response rate investor yang kecil, (2) sampel dalam penelitian tergolong kecil; (3) subyektifitas peneliti dalam menilai tingkat VCGD (Indeks Pengungkapan Relatif atau IPR) masing-masing perusahaan.

Peneliti selanjutnya disarankan (1) untuk menambah besaran sampel penelitian, sehingga diharapkan hasil penelitian selanjutnya dapat lebih digeneralisasi dengan baik; (2) Penilaian IPR dapat dilakukan dengan melibatkan beberapa peneliti sehingga dapat memperkecil tingkat subyektifitas penilaian indeks pengungkapan corporate governance.

\section{DAFTAR PUTAKA}

Ghozali, I. 2006. Aplikasi Analisis Multivariate dengan Program SPSS. Semarang: Badan Penerbit Universitas Diponegoro.

Healy, P. and Palepu K. 2001. "Information Asymmetry, Corporate Disclosure, and the Capital Markets: A Review of the Empirical Disclosure Literature", Journal of Accounting and Economics, 31(1-3), pp. 405-440. http://papers.ssrn.com/ sol3/papers.cfm?abstract_id=258514. Diakses tanggal 17 Januari 2011.

Hrasky, S. and P. Collet. 2005. "Voluntary Disclosure of Corporate Gover n a n ce Practices by Listed Australian Companies". Vol.13, No.2; March. USA: Blackwell Publishing Ltd.

Ho, S.S.M., \& Wong, K.S. 2001. "A study of the relationship between corporate governance structures and the extent of voluntary disclosure". Journal of International Accounting, Auditing \& Taxation. Vol.10, No.2, pp.139-157.

Komite Nasional Kebijakan Governance. 2006. Pedoman Umum Good CorporateGovernance Indonesia, Jakarta.

Kusumawati, D.N. 2007. "Profitability and Corporate Governance Disclosure:An Indonesian Study", Jurnal Riset Akuntansi Indonesia, Vol. 10, No. 2, Hal. 131-146.

Maingot, M. and D. Zeghal. 2008. "An Analysis of Corporate Governance Information By Canadian Banks". Corporate Ownership \& Control. Vol.5, Issue 2. Winter. 
VCGR

Versi

Investor...

312
Mohamad and Sulong. 2010. "Corporate Governance Mechanisms and Extent of Disclosure: Evidence from Listed Companies in Malaysia”. International Business Research. Vol. 3, No. 4; October. pp.216-228. http://www.ccsenet.org/ibr. Diakses tanggal 15 Desember 2010.

Rini, A. K. 2010. "Analisis Luas Pengungkapan Corporate Governance DalamLaporan Tahunan Perusahaan Publik di Indonesia". Skripsi Tidak Dipublikasikan. Fakultas Ekonomi Universitas Diponegoro.

Safitri, A. 2008. "Pengaruh Profitabilitas Terhadap Tingkat Pengungkapan Corporate Governance. Studi empiris pada perusahaan yang terdaftar dalam Jakarta Islamic Index)". Skripsi Tidak Dipublikasikan. Fakultas Ekonomi Universitas Diponegoro.

Simanjuntak, L. K. 2009. "Hubungan Karakteristik Perusahaan Terhadap Luas Pengungkapan Sukarela di Indonesia (Studi Pada Perusahaan Manufaktur Dan Non-Manufaktur Yang Listing di Bursa Efek Indonesia)”. Skripsi Tidak Dipublikasikan. Fakultas Ekonomi Universitas Diponegoro.

Subroto, V. K. 2009. "Hubungan Karakteristik Perusahaan Terhadap Luas Pengungkapan Sukarela di Indonesia (Studi pada Perusahaan Manufaktur Yang Listing di BEI)". Skripsi Tidak Dipublikasikan. Fakultas Ekonomi Universitas Diponegoro.

Vasthi, K. 2009. "Pengaruh Karakteristik Perusahaan, Struktur Kepemilikan, dan Mekanisme $C G$ Terhadap Tingkat Pengungkapan Laporan Keuangan (Studi Pada Perusahaan Manufaktur Yang Terdaftar di Bursa Efek Indonesia Tahun 2005-2007)". Skripsi Tidak Dipublikasikan. Fakultas Ekonomi Universitas Diponegoro.

Wijayanti, D. 2009. "Pengaruh Karakteristik Perusahaan Terhadap Luas Pengungkapan Perusahaan (Studi pada Perusahaan Sektor Keuangan Dan Non-Keuangan Yang Listing di BEI 2006-2007)". Skripsi Tidak Dipublikasikan. Fakultas Ekonomi Universitas Diponegoro.

Yuen, C.Y. Desmond, M.Liu, Xu Zhang, and Chan Lu. 2009. "A Case Study of Voluntary Disclosure by Chinese Enterprises". Asian Journal of Finance \& Accounting. Vol. 1, No. 2: E6. pp. 118-145 